\title{
Caracterization from hearing thresholds from dentists in a poulation from Curitiba city / PR, Brazil
}

\section{Caracterização dos limiares auditivos de odontólogos numa população da cidade de Curitiba - PR, Brasil}

\author{
Cláudia Giglio de Oliveira Gonçalves', Jair Mendes Marques², Angela Ribas 3 , Adriana Bender Moreira de Lacerda4, Diolen \\ Conceição Barros Lobato ${ }^{5}$, Gisele Lacerda Costa ${ }^{6}$, Geyza Aparecida Gonçalves ${ }^{7}$.
}

1) $\mathrm{PhD}$ in Collective Health. Professor of Master's Degree Program in Communication Disorder UTP.

2) PhD in Geodetic Science. Professor of Master's Degree Program in Communication Disorder UTP.

3) PhD in Environment and Urban Development. Professor of Master's Degree Program in Communication Disorder UTP.

4) $\mathrm{PhD}$ in Biomedical Sciences Audiology. Professor of Master's Degree Program in Communication Disorder UTP.

5) Master in Communication Disorder. Professor of Speech Therapy Course of UNAMA

6) Master in Communication Disorder. Nurse at Clínicas Hospital /PR.

7) Undergraduate Nursing. Scientific Initiation Scholarship.

Institution: Tuiuti University of Paraná.

Curitiba / PR - Brazil.

Mailing Address: Cláudia Giglio de O. Gonçalves - 146, Felisberto Fiore Darozio, St. - Curitiba / PR - Brazil - Zip-code: $82410-460$ - Telephone: (+55 41) 3331-7848 -E-mail: claudia.goncalves@utp.brou claudia.giglio@ hotmail.com

Article received in 2011 May $16^{\text {th }}$. Article approved in 2011 June $30^{\text {th }}$

\section{SUMMARY}

Introduction: The dentists are exposed to noise in their work place, being likely to develop of hearing loss neurosensory with induced characteristics by noise.

Objective: Analyze the hearing thresholds from dentists characterizing them according to gender, age and time of service.

Method: The form of the study is cross-section (or sectional), prospective, that analyzed the hearing thresholds from 115 dentists, through tone audiometry of $500 \mathrm{~Hz}$ to $8000 \mathrm{~Hz}$ by airway or bone conduction. Were analyzed the tonal hearing thresholds from the group of dentists by gender, regarding the age and time of service and applied statistical procedures for the edition of data.

Results: Were observed average tonal hearing thresholds with configuration from acoustic notch, being more accentuated in the male gender. There is sensorineural hearing loss in 28 $(24,34 \%)$ dentists, $8(14,54 \%)$ between female gender and 20 $(33,33 \%)$ between the male gender, the proportion of subjects with altered hearing is significantly bigger in the male gender $(p=0,0208)$. The tonal hearing thresholds for the male gender shown to be worse than in the females when analyzed by age and time of service, but the men were older and with more time of service than the women.

Conclusion: The dentists presented sensorineural hearing loss with acoustic notch (being more present in the male gender) with worsening of hearing and time of service, especially after 21 years of work.

Keywords: dentists, occupational diseases, hearing loss provoked by noise.

\section{RESUMO}

Introdução: Os odontólogos estão expostos ao ruído em seu local de trabalho, sendo susceptíveis para o desenvolvimento de perda auditiva sensorioneurais com características de induzida por ruído.

Objetivo: Aanalisar os limiares auditivos de odontólogos caracterizando-os em relação ao gênero, idade e tempo de serviço. Método: A forma do estudo é corte transversal (ou seccional), prospectivo, que analisou os limiares auditivos de 115 odontólogos, através de audiometria tonal de $500 \mathrm{~Hz}$ a $8000 \mathrm{~Hz}$ por via aérea e via óssea. Foram analisados os limiares auditivos tonais do grupo de odontólogos por gênero, em relação à idade e tempo de serviço e aplicados procedimentos estatísticos para a edição dos dados.

Resultados: Observaram-se limiares auditivos tonais médios com configuração de entalhe acústico, sendo mais acentuados no gênero masculino. Há perda auditiva sensorioneural em 28(24,34\%) odontólogos, 8 (14,54\%) entre o gênero feminino e 20 (33,33\%) entre o gênero masculino, a proporção de sujeitos com audição alterada é significativamente maior no gênero masculino ( $\mathrm{p}=0,0208)$. Os limiares auditivos tonais para o gênero masculino apresentaram-se piores do que no feminino quando analisados por idade e tempo de serviço, porém os homens do estudo eram mais velhos e com mais tempo de serviço que as mulheres.

Conclusão: Os odontólogos apresentaram perdas auditivas sensorioneurais com entalhe acústico (sendo mais presentes entre o gênero masculino) com piora auditiva com a idade e tempo de serviço, principalmente após 21 anos de trabalho Palavras-chave: odontólogos, doenças profissionais, efeitos do ruído, perda auditiva provocada por ruído. 


\section{INTRODUCTION}

Noise is known as an agent aggressive to the ears common in work environment and responsible for Hearing Losses Induced by Noise (PAIR) in different branch of activities (1). It is considered PAIR a hearing change with sensorioneural characteristic, cochlear, which affects especially the frequencies of 3000 to $6000 \mathrm{~Hz}$ $\mathrm{Hz}$, always almost bilateral and irreversible.

According to Brazilian Labor Legislation, Norm 15 - NR15 (2), a work environment will be considered of risk to development of hearing loss when exceed $85 \mathrm{dBA}$ for a journey of 8 hours of work. In the Norm 17 - NR17 (3), which is based on Brazilian Norm - NBR n. 10152 (4), it is established that for purposes of acoustic comfort, the maximum level of noise in dental offices must be of $45 \mathrm{dBA}$ to 50dBA. Research showed that clinic, the offices and dental laboratories presented high sound pressure levels which lead, in time, impairments to the health of the professionals who work there, like as PAIR among others (5-10).

Study in Brazil found high level pressure of sound in the odontological equipments from a brand largely used, namely: in high rotation 65 to $78,6 \mathrm{dBA}$, in the amalgam 65,8 to $68 \mathrm{dBA}$, in sucker of high-power 68,8 a $72 \mathrm{dBA}$, in ultrasound for cleaning teeth 75,8 to $88 \mathrm{dBA}$ and in the low speed engine 69,8 to $72 \mathrm{dBA}$ (11).

Even if the noise level found in dental offices is not of sufficient intensity to cause hearing damages, it may cause discomfort and other non auditory symptoms to the professional (12). Among the non auditory symptoms associated to the noise exposure there are changes involving neurological system, circulatory systems, digestive system, endocrine system, immunological system and psyche (13). In study of 30 dental surgeons, of both of genders, it was found complaints possibly associated to exposure to noise: buzz (37\%), insomnia (30\%), headache (27\%) and nausea (20\%) (10).

Despite of the effects of the noise are preventable, the adoption of preventive measures among the dentist is still incipient. Among these measures there is the use of ear protection, still not completely incorporated among the dentist's individual protection equipment (5, 14).

Once that the dentist's work environment present high level of noise, therefore, a risk to occur hearing losses, arises the need to comprehend better how they occur, aiming the precocious diagnosis and interventions.

\section{MethOD}

It is a study cross-section (or sectional) which analyzed the hearing thresholds of dentists (total of 115) of both of genders, at city of Curitiba / PR.

The criteria inclusion for this study was the dentist is active, voluntary, without compromise of external or middle ear and sign the Statement of Consent. The research was approved by the Ethics Committee of the proposing institution under n. 017/2008.

The dentists were submitted to the inspection of the external auditory and to tone audiometry of $500 \mathrm{~Hz}$ to $8000 \mathrm{~Hz}$ by airway and by bone conduction (If necessary, in other words, tone thresholds greater than air to $30 \mathrm{dBNA}$ ) using audiometer MAICO MA 41 (calibrated according to the pattern ANSI 1969) in acoustic cabin (calibrated by Norm I.S.O. 8253-1 of 1989), by a speech therapist, expert in audiology. It was considered the tone auditory threshold of $25 \mathrm{dBNA}$ in all of frequencies, as normal range. The dentists were questioned about current and previous diseases and morbid history which may cause hearing loss.

It excluded the cases with audiograms which indicated hearing loss of the type conductive and mixed, hearing disturbs associated to diseases or significative extra-occupational exposure.

We analyzed the tone hearing thresholds of group of dentists by gender, related to gender and time of service as dentist.

It was applied statistical procedures for data edition through the software Statistica-Release 7, and a survey of significant relationships and results of audiometry, considering if age and time of service to a significance of level de 0,05 (5\%).

\section{RESULTS}

It was analyzed the auditory thresholds of 115 dentists of both of gender, 55 (47,82\%) of feminine gender and $60(52,17 \%)$ of masculine gender.

The audiometry threshold revealed a change, with sensorioneural hearing loss, in 28 (24,34\%) dentists, being $8(14,54 \%)$ feminine gender and $20(33,33 \%)$ of masculine gender. Through the proportion difference test, we can declare, the significance level 0,05 (5\%), which the proportion of the subjects with hearing change it was significantly greater than the dentist of masculine gender $(\mathrm{p}=0,0208)$. 
The mean auditory threshold for each gender that was found are represented in the Figures 1 e 2.

Through T-Student test was observed significant difference between the genders, to the auditory threshold to the right in the frequencies of de $3.000 \mathrm{~Hz}(\mathrm{p}=0,009)$, $4.000 \mathrm{~Hz}(\mathrm{p}=0,001), 6.000 \mathrm{~Hz} \quad(\mathrm{p}=0,036)$ and $8.000 \mathrm{~Hz}$ $(p=0,010)$.

Through T-Student test was observed significant difference between the genders, to the auditory threshold to the left in frequencies of $1.000 \mathrm{~Hz}(\mathrm{p}=0,044), 2.000 \mathrm{~Hz}$ $(p=0,008), 3.000 \mathrm{~Hz} \quad(p=0,002), 4.000 \mathrm{~Hz} \quad(p=0,000)$, $6.000 \mathrm{~Hz}(\mathrm{p}=0,024)$ and $8.000 \mathrm{~Hz}(\mathrm{p}=0,013)$.

Related to the variable age, the average among the dentists were of 40 years ( $\mathrm{DP}=4,2$ years-old). In feminine gender, the average age was of 37,8 years-old $(\mathrm{DP}=9,3)$ and in the masculine gender was of 42,9 years-old ( $\mathrm{DP}=11,7)$, occurring difference statistically significant between the gender related to the age $(\mathrm{p}=0,002)$.

By analyzing the mean of the auditory threshold in function of age average, separated by gender, we observed the results presents on Tables 1 and 2 .

Occurs a significant worsening (positive correlation) in auditory threshold to the age variable, in feminine gender, at the following frequencies: in the right ear in $3.000 \mathrm{~Hz}, 4.000 \mathrm{~Hz}$ and in the left ear in $3.000 \mathrm{~Hz}, 4.000 \mathrm{~Hz}, 6.000 \mathrm{~Hz}$ and $8.000 \mathrm{~Hz}$; and in the masculine gender, in the right ear in $2.000 \mathrm{~Hz}, 3.000 \mathrm{~Hz}$, $4.000 \mathrm{~Hz}, 6.000 \mathrm{~Hz}, 8.000 \mathrm{~Hz}$; and in the left ear from $500 \mathrm{~Hz}$ to $8.000 \mathrm{~Hz}$. The auditory threshold in masculine presented the worst than the feminine gender, considering age.

The average time of service a dentist was of 16,6 year ( $\mathrm{DP}=3,5$ years). In the feminine gender was of 14,1 years ( $D P=9,9$ years) and in the masculine gender of 18,8 years $(\mathrm{DP}=10,7)$, occurring significative statistically difference between the genders related to the time of service $(p=0,0129)$.

The time of service in function of hearing profile, in both genders is represented in Table 3.

The percentage of hearing changes related to the time of service was superior among men. From 21 years of time of service, observed a greater percentage of hearing changes in the group of masculine gender.

The auditory threshold mean in function of time of service as dentist, in both genders, are registered on Tables 4 e 5 .

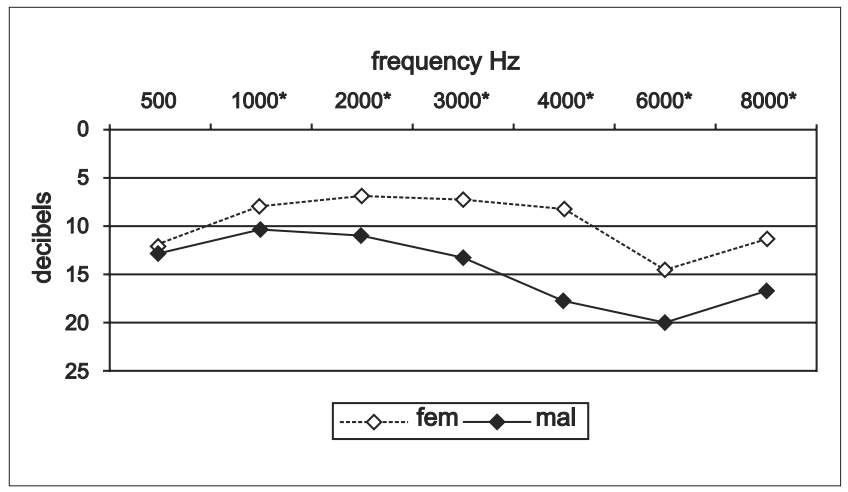

Figure 1. Mean auditory threshold, in both genders, to right ear $(\mathrm{N}=115)$ (attached as image). OBS: $* p<0,05$

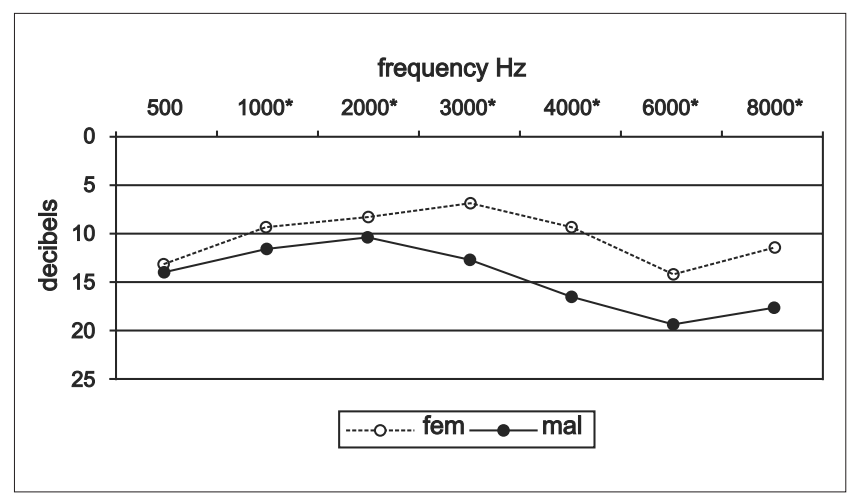

Figure 2. Mean auditory threshold, in both genders, to left ear ( $\mathrm{N}=115$ ) (attached as image). OBS: $* p<0,05$

Occurred significative correlation simultaneously between time of service and gender, being the masculine gender has a compromising in greater number of tonal frequencies in function of time of service.

It was investigated a daily work journey of dentists, being the average of 11 hours/day ( $D P=2,8$ hours) and there was not differences statistically significative between the genders for daily work journey $(p=0,1123)$.

\section{DisCusSiON}

The dentist group studied (total 115) was composed by $52,17 \%$ men, which presented average age and time of service superior to the women.

It was observed sensorioneural hearing losses in $24,34 \%$ of dentists. Other studies with dentists in Brazil were found also sensorioneural hearing losses, but in greater percentage than this, such as study in Paraná, with 85 surgeon dentists, were found 43,5\% with hearing changes (9); in a study at Ribeirão Preto/SP (15) with 40 
Table I. Correlation between age and auditory threshold in femininegender $(n=55)$.

\begin{tabular}{|c|c|c|c|c|c|c|}
\hline $\begin{array}{l}\text { Earand } \\
\text { Frequency }\end{array}$ & \multicolumn{2}{|c|}{ Average } & \multicolumn{2}{|c|}{$\begin{array}{l}\text { Standard } \\
\text { Deviation }\end{array}$} & $\mathrm{R}$ & $P$ \\
\hline \multicolumn{7}{|c|}{ RightEar } \\
\hline 500 & 36,8 & 13,1 & 9,3 & 4,7 & 0,17 & 0,2235 \\
\hline 1.000 & 36,8 & 9,3 & 9,3 & 4,9 & 0,18 & 0,1910 \\
\hline 2.000 & 36,8 & 8,4 & 9,3 & 5,5 & 0,18 & 0,1891 \\
\hline 3.000 & 36,8 & 6,9 & 9,3 & 6,0 & 0,37 & 0,005 I* \\
\hline 4.000 & 36,8 & 9,4 & 9,3 & 6,9 & 0,40 & $0,0026 *$ \\
\hline 6.000 & 36,8 & 14,2 & 9,3 & 7,9 & 0,17 & $0,21 \mid 9$ \\
\hline 8.000 & 36,8 & $1 \mid, 4$ & 9,3 & 8,2 & 0,29 & 0,0335 \\
\hline \multicolumn{7}{|c|}{ LeftEar } \\
\hline 500 & 36,8 & $|2|$, & 9,3 & 4,9 & $-0,04$ & 0,7493 \\
\hline 1.000 & 36,8 & 8,0 & 9,3 & 4,6 & 0,21 & 0,1261 \\
\hline 2.000 & 36,8 & 6,9 & 9,3 & 5,7 & 0,20 & $0,|4| \mid$ \\
\hline 3.000 & 36,8 & 7,2 & 9,3 & 5,7 & 0,28 & 0,0393* \\
\hline 4.000 & 36,8 & 8,3 & 9,3 & 6,2 & 0,39 & 0,003 |* \\
\hline 6.000 & 36,8 & 14,4 & 9,3 & 8,2 & 0,47 & $0,0053 *$ \\
\hline 8.000 & 36,8 & 11,3 & 9,3 & 8,5 & 0,46 & $0,0004 *$ \\
\hline
\end{tabular}

Obs. Pearson's correlation. * level of significance 5\%
Table 2. Correlation between age and auditory threshold in masculine gender $(n=60)$.

\begin{tabular}{|c|c|c|c|c|c|c|}
\hline $\begin{array}{l}\text { Earand } \\
\text { Frequency }\end{array}$ & \multicolumn{2}{|c|}{ Average } & \multicolumn{2}{|c|}{$\begin{array}{l}\text { Standard } \\
\text { Deviation }\end{array}$} & $\mathrm{R}$ & $P$ \\
\hline \multicolumn{7}{|c|}{ RightEar } \\
\hline 500 & 43,0 & 13,9 & 11,8 & 12,0 & 0,16 & 0,2304 \\
\hline 1.000 & 43,0 & 11,6 & 11,8 & 11,8 & 0,25 & 0,0600 \\
\hline 2.000 & 43,0 & 10,6 & $\mid 1,8$ & $\mid 1,4$ & 0,47 & 0,0002 * \\
\hline 3.000 & 43,0 & 12,8 & 11,8 & 15,0 & 0,54 & $0,0000 *$ \\
\hline 4.000 & 43,0 & 16,8 & 11,8 & $|5|$, & 0,55 & $0,0000 *$ \\
\hline 6.000 & 43,0 & 19,7 & 11,8 & 16,6 & 0,63 & $0,0000 *$ \\
\hline 8.000 & 43,0 & 18,0 & 11,8 & 16,4 & 0,63 & $0,0000 *$ \\
\hline \multicolumn{7}{|c|}{ LeftEar } \\
\hline 500 & 43,0 & 12,8 & 11,8 & 5,2 & 0,45 & 0,0003 * \\
\hline 1.000 & 43,0 & 10,2 & 11,8 & 6,6 & 0,55 & $0,0000 *$ \\
\hline 2.000 & 43,0 & ||$, \mid$ & 11,8 & 10,0 & 0,53 & $0,0000 *$ \\
\hline 3.000 & 43,0 & 13,1 & 11,8 & 13,3 & 0,54 & $0,0000 *$ \\
\hline 4.000 & 43,0 & 17,8 & 11,8 & 14,6 & 0,62 & $0,0000 *$ \\
\hline 6.000 & 43,0 & 20,0 & 11,8 & 16,0 & 0,60 & $0,0000 *$ \\
\hline 8.000 & 43,0 & 18,2 & 11,8 & 18,3 & 0,40 & $0,00 \mid 7 *$ \\
\hline
\end{tabular}

Obs. Pearson's correlation. * level of significance $5 \%$

Table 3. Service time and hearing profile of dentists $(N=|| 5)$.

\begin{tabular}{|c|c|c|c|c|c|c|c|c|c|c|}
\hline \multirow[t]{3}{*}{ Time(years) } & \multicolumn{4}{|c|}{ NormalHearing } & \multicolumn{4}{|c|}{ ChangedHearing } & \multicolumn{2}{|c|}{ Total } \\
\hline & \multicolumn{2}{|c|}{ feminine } & \multicolumn{2}{|c|}{ masculine } & \multicolumn{2}{|c|}{ feminine } & \multicolumn{2}{|c|}{ masculine } & \multirow{2}{*}{$\begin{array}{c}\text { feminine } \\
\mathrm{n}\end{array}$} & \multirow{2}{*}{$\begin{array}{c}\text { masculine } \\
n\end{array}$} \\
\hline & $\mathrm{n}$ & $\%$ & $n$ & $\%$ & $n$ & $\%$ & $\mathrm{n}$ & $\%$ & & \\
\hline I to 10 & 22 & 95,65 & 13 & 100,0 & I & 4,34 & 0 & 0 & 23 & 13 \\
\hline I | to 20 & 12 & 80,00 & 12 & 80,00 & 3 & 20,00 & 3 & 20,00 & 15 & 15 \\
\hline 21 to 30 & 13 & 76,47 & 15 & 55,55 & 4 & 23,52 & 12 & 44,44 & 17 & 27 \\
\hline 31 or more & - & - & 0 & 0 & - & - & 5 & 100,0 & - & 5 \\
\hline
\end{tabular}

Table 4. Service time and mean hearing threshold in feminine gender, by Pearson 's correlation $(n=55)$.

\begin{tabular}{|c|c|c|c|c|c|c|}
\hline $\begin{array}{l}\text { Earand } \\
\text { Frequency }\end{array}$ & \multicolumn{2}{|c|}{ Average } & \multicolumn{2}{|c|}{$\begin{array}{l}\text { Standard } \\
\text { Deviation }\end{array}$} & $R$ & $P$ \\
\hline \multicolumn{7}{|c|}{ RightEar } \\
\hline 500 & $|4|$, & $|3|$, & 9,3 & 4,7 & 0,14 & 0,2982 \\
\hline 1.000 & $|4|$, & 9,3 & 9,3 & 4,9 & 0,14 & $0,3 \mid 15$ \\
\hline 2.000 & $|4|$, & 8,4 & 9,3 & 5,5 & 0,16 & 0,2501 \\
\hline 3.000 & $|4|$, & 6,9 & 9,3 & 6,0 & 0,36 & $0,0066 *$ \\
\hline 4.000 & $|4|$, & 9,4 & 9,3 & 6,9 & 0,40 & $0,0025 *$ \\
\hline 6.000 & $|4|$, & 14,2 & 9,3 & 7,9 & 0,10 & 0,4741 \\
\hline 8.000 & $|4|$, & 11,4 & 9,3 & 8,2 & 0,22 & 0,1097 \\
\hline \multicolumn{7}{|c|}{ LeftEar } \\
\hline 500 & $|4|$, & $12, \mid$ & 9,3 & 4,9 & $-0,06$ & 0,6884 \\
\hline 1.000 & $|4|$, & 8,0 & 9,3 & 4,6 & 0,12 & 0,3668 \\
\hline 2.000 & $|4|$, & 6,9 & 9,3 & 5,7 & 0,13 & 0,3292 \\
\hline 3.000 & $|4|$, & 7,2 & 9,3 & 5,7 & 0,20 & 0,1367 \\
\hline 4.000 & $|4|$, & 8,3 & 9,3 & 6,2 & 0,36 & 0,007 I \\
\hline 6.000 & $|4|$, & 14,4 & 9,3 & 8,2 & 0,31 & $0,0220 *$ \\
\hline 8.000 & $|4|$, & 11,3 & 9,3 & 8,5 & 0,38 & $0,0037 *$ \\
\hline
\end{tabular}

* level of significance $5 \%$
Tabela 5. Service time and mean hearing threshold in masculine gender, by Pearson's correlation $(n=60)$.

\begin{tabular}{|c|c|c|c|c|c|c|}
\hline $\begin{array}{l}\text { Earand } \\
\text { Frequency }\end{array}$ & \multicolumn{2}{|c|}{ Average } & \multicolumn{3}{|c|}{$\begin{array}{l}\text { Standard } \\
\text { Deviation } \\
\text { Age Threshold }\end{array}$} & $P$ \\
\hline \multicolumn{7}{|c|}{ RightEar } \\
\hline 500 & 18,8 & 13,9 & 10,8 & 12,0 & 0,20 & 0,1348 \\
\hline 1.000 & 18,8 & 11,6 & 10,8 & $1 \mid, 8$ & 0,24 & 0,0693 \\
\hline 2.000 & 18,8 & 10,6 & 10,8 & $1 \mid, 4$ & 0,48 & $0,000 \mid *$ \\
\hline 3.000 & 18,8 & 12,8 & 10,8 & 15,0 & 0,57 & $0,0000 *$ \\
\hline 4.000 & 18,8 & 16,8 & 10,8 & $|5|$, & 0,58 & $0,0000 *$ \\
\hline 6.000 & 18,8 & 19,7 & 10,8 & 16,6 & 0,61 & $0,0000 *$ \\
\hline 8.000 & 18,8 & 18,0 & 10,8 & 16,4 & 0,59 & $0,0000 *$ \\
\hline \multicolumn{7}{|c|}{ LeftEar } \\
\hline 500 & 18,8 & 12,8 & 10,8 & 5,2 & 0,44 & $0,0005 *$ \\
\hline 1.000 & 18,8 & 10,2 & 10,8 & 6,6 & 0,52 & $0,0000 *$ \\
\hline 2.000 & 18,8 & $1 \mid, 2$ & 10,8 & 10,0 & 0,54 & $0,0000 *$ \\
\hline 3.000 & 18,8 & 13,1 & 10,8 & 13,3 & 0,54 & 0,0000 * \\
\hline 4.000 & 18,8 & 17,8 & 10,8 & 14,6 & 0,60 & $0,0000 *$ \\
\hline 6.000 & 18,8 & 20,0 & 10,8 & 16,0 & 0,58 & $0,0000 *$ \\
\hline 8.000 & 18,8 & 18,2 & 10,8 & 18,3 & 0,36 & $0,0049 *$ \\
\hline
\end{tabular}

* level of significance $5 \%$ 
dentists of both genders, all of them with more than five years in profession, occurred $70 \%$ of hearing losses; and at Goiás, study with 228 dentists were found 31,58\% with suggestive hearing changes of PAIR (16). In the research performed with 30 surgeon dentists in both of genders, it was found $17 \%$ of hearing changes in high frequencies (3 and/or 4 and/or $6 \mathrm{kHz}$ ), lower percentage than this study (10). And, in a study performed in Belgium, the authors found hearing changes of $19,6 \%$ of dentists, especially in masculine gender(6).

The mean auditory threshold of dentists presented configuration of acoustic notch (Figure 1 e 2) and the significative differences between the genders related to the frequencies 3.000, 4.000, 6.000 e 8.000 Hertz bilaterally and in 1.000 e 2.000 Hertz in the left ear. It was found predominance of hearing changes in the men group (33,33\%). Other studies analyzed hearing loss at work, with inferences from the gender, also it was observed the predominance of hearing changes in masculine gender with configuration of acoustic notch, typical of noiseinduced hearing loss $(17,18)$. According to the literature (19-22), the hearing losses a work affect especially the masculine gender which, possibly, is more susceptible and more exposed to the factors of risk, when compared to feminine gender. It is estimated that the prevalence of hearing loss in adults in western industrialized countries of 77 by 1.000 in masculine gender 70 by 1.000 in feminine gender (23). However, it should be considered that in this present study, the masculine gender presented superior age and time of service superior than the feminine gender, what may had influenced on results.

Time of service relates to the age. Several studies shows a progression of hearing thresholds due to the age and time of service, considering that the greater the length of service greater is the exposition to the occupational risks (17, 24-27).

Studies show the effects of age and time of exposure to the noise (in years) about the worker, considering that the both effects overlap damaging the cochlea hair cells $(24,28)$.

It was observed (Tables 1 and 2) that there is a significative worsening (positive correlation) in the auditory threshold to the age variable (with increasing age, the auditory threshold gets worse) in both genders, especially to the high frequencies which are more affected by the noise as well as to the aging.

Related to the time of service, in masculine gender occurred a greater percentage of hearing changes especially from 21 years of time of service (Table 3). Although, it is important to highlight that the men group of this study presented time of service superior than the women group, which it may interfered on the results. Some of the studies with other worker segments exposed to the noise, shows the development of PAIR after 10 years of work exposed to the intense noise, 8 hours a day $(13,17)$.

In the auditory threshold analysis in function of length of service (Tables 4 and 5), the significative worsening (positive correlation), in feminine gender, occurred in high frequencies, in $3.000 \mathrm{~Hz}$ and $4.000 \mathrm{~Hz}$ in the right ear, considered by the literature the main affected by the noise; and $4.000 \mathrm{~Hz}, 6.000 \mathrm{~Hz}$ and $8.000 \mathrm{~Hz}$, in the left ear. And in masculine gender, it was affected a greater extension of frequencies (from $2.000 \mathrm{~Hz}$ to $8.000 \mathrm{~Hz}$ in right ear and in all of frequencies in left ear), what may characterize the influence of age together to the length of service. In study with workers exposed to noise was observed that age and time of service favored lowering of auditory threshold, as according of aging and length of service, more frequencies presented changes in audiogram (27). In other study (17) with 5372 workers of masculine gender exposed to noise, 1019 (19\%) presented hearing loss, from this 90,67\% these are compatible with noise exposure, being the age group more affected over of 45 years (47,20\% of PAIR), the time of exposure above 20 year with $51,20 \%$ of cases of PAIR. These findings are close to the found in this study, which found in masculine gender 54,44\% of hearing changes after 21 years of service.

Related to the daily working hours, analyzed in hours, both of groups are similar and work in average 11 hours/daily, what may increase the risk of hearing changes depending on the daily dose of noise that they got exposed (13).

\section{CONCLUSION}

The dentists of this study presented mean auditory threshold with configuration in acoustic notch. The sensorioneural hearing losses were present in $24,34 \%$ of dentists, being that among masculine gender the changes were significantly superior $(33,33 \%)$.

The auditory threshold worsen as aging and service time, being in the masculine gender these factors more impacting than in feminine gender. After 21 years of length of service, the hearing change percentage was greater in dentists of masculine gender.

The dentists of masculine gender in this study presented age and service time superior to feminine gender.

It is suggested that further studies comparing the 
auditory threshold between the genders involve a population more homogeneous related to the age and service time.

\section{BIBLIOGRAPHIC REFERENCES}

1. Gonçalves CGO, Lacerda ABM, Ribas A, Oliva FC, Almeida SB, Marques JM. Exposição ocupacional ao ruído em odontólogos do Paraná: percepção e efeitos auditivos. Rev Odontol UNESP. 2009, 38(4):235-43.

2. Brasil - Ministério do Trabalho e Emprego. Portaria 3.214 de jul. 1978. Normas regulamentadoras de segurança e saúde no trabalho (NR-15): Atividades e operações insalubres. Brasília, 1978. Disponível em: <http:// www.mte.gov.br/temas/segsau/legislacao/normas/ conteudo/nr15>. Acesso em: 23/09/2010

3. Brasil-Ministério do Trabalho e Emprego. Portaria 3.214 de jul. 1978. Normas regulamentadoras de segurança e saúde no trabalho (NR 17): Ergonomia. Brasília, 1998. Disponível em: <http://www.mte.gov.br/temas/segsau/ legislacao/normas/conteudo/nr17>. Acesso em: 23/09/2010

4. Associação Brasileira de Normas Técnicas (ABNT). NBR 10152: Níveis de ruído para conforto acústico em ambientes diversos. Rio de Janeiro; 2000.

5. Gonçalves CGO, Ribas A, Lacerda ABM, Gonçalves GA, Albizu E. A exposição ao ruído na prática da odontologia. IN: Morata TC, Zucki FM(org). Saúde Auditiva: Avaliação de Riscos e Prevenção. São Paulo: Plexus, 2010.

6. Gijbels F, Jacobs R, Princen K, Nackaerts O, Debruyne F. Potential occupational health problems for dentist in Flandres. Clin Oral Invest. 2006, 10:8-16.

7. Bali N, Acharya S, Anup N. An assessment of the effec of sound produced in a dental clinic on the hearing of dentist. Oral Health Prev Dent. 2007, 5:187-91.

8. Paraguay ATT. Perda induzida por ruído em consultório odontológico. Recife, 1999, 30p. (Monografia de Especialização em Audiologia-CEFAC).

9. Mota SSR. Limiares Auditivos de cirurgiões-dentistas nas freqüências 250 a 16.000Hz. In: Morata TC, ZUCKI F (org). Caminhos para a Saúde Auditiva: ambiental - ocupacional. São Paulo: Plexus; 2005.

10. Lelo NMV, Ricco FF, Sabo VA, Netto MP, Ricco RAPO. Avaliação do Limiar Auditivo em Profissionais de Odontologia. Colloquium Vitae. 2009, 1(1):71-74.

11. Berro RJ, Nerm K. Avaliação dos ruídos emalta freqüência dos aparelhos odontológicos. Rev CEFAC. 2004, 6(4): 3005 .

12. Lacerda A, Melo SCS, Mezzadri SD, Zonta WG. Nível de pressão sonora de um consultório odontológico: uma análise ergonômica. Tuiuti Ciência e Cultura. 2002, 26(03):17-24.

13. Gonçalves CGO. Saúde do Trabalhador: da estruturação a avaliação de programas de preservaçãoauditiva. São Paulo: Roca, 2009.

14. Torres BO, Fernandes MJM, Felix SSS, Costa ICC. A Perda auditiva induzida por ruído na formação acadêmica: conhecimentos e medida de prevenção. Odontol ClínCientíf. 2007, 6(2):151-154.

15. Berbare GM, Fukusima SS. Perda auditiva induzida por ruído de motores de alta-rotação em odontólogos e alunos de odontologia: análise audiométrica em freqüência entre 250Hz a 16 KHz. Rev Bras Saúde Ocup. 2003, 28(107/ 108):28-38.

16. Santana KD. PAIR em dentistas: atuação odontológica e sua relação com a perda auditiva induzida pelo ruído. Rev Fono Atual. 2000, 13:8-21.

17. Teles RM, Medeiros MPH. Perfil audiométrico de trabalhadores do distrito industrial de Maracanaú-CE. Rev Soc Bras Fonoaudiol. 2007, 12(3):233-39.

18. Jerger S, Jerger, G. Alterações Auditivas: um manual para avaliação clínica. São Paulo: Atheneu, 1989.

19. Moller MB. Hearing in 70 and 75 years old people: results from a cross sectional and longitudinal population. J Otol. 1981, 2:22-9.

20. Gates GA, Schmid P, Kuyawa SG, Wan B, D'Agostinho R. Longitudinal threshold changes in older men with audiometric notches. Hear Res. 2000, 141(1-2):220-28.

21. Pearson JD, Morrel CH, Godon-Salant S, et al. Gender differences in a longitudinal study of age-associated hearing loss. J Acoust Soc Am. 1995, 97(2):1196-205.

22. Caldart UA, Adriano C F, Terruel I, Martins RF, Caldart UA, Mocellin M. Prevalência da perda auditiva induzida pelo ruído em trabalhadores de indústria têxtil. Arq Int Otorrinolaringol. 2006, 10(3):192-96.

23. Surjan L, Devald J, Palfalvi L. Epidemiology of hearing loss. Audiol. 1973, 12:346-410.

24.Gonçalves CGO, Mota PHM, Marques JM. Ruído e idade: 
análise da influência na audição em indivíduos de 50-70 anos. Rev Pro-fono. 2009, 21(4):57-61.

25.Toppila E, Pyykko I, Starck J. Age and noise-induced hearing loss. Scand Audiol. 2001, 30:236-244.

26. Santos JD, Ferreira MIDC. Variação dos Limiares Audiométricos em Trabalhadores Submetidos a Ruído Ocupacional. Arq Int Otorrinolaringol. 2008, 12(2): 201-9.
27. Lopes AC, Otubo KA, Basso TC, Marinelli EJI, Lauris JRP. Perda Auditiva Ocupacional: Audiometria Tonal X Audiometria de Altas Freqüências. Arq Int Otorrinolaringol. 2009, 13(3):293-299.

28. Gates GA, Cooper JC, William BK, Miller NJ. Hearing in the Elderly: The Framingham Cohort, 1983-1985. Ear Hear. 1990, 11(Pt 1):247-56. 